\title{
Student Career Orientation Mechanical Engineering Diploma (D-III) Polytecnic of Kediri
}

\author{
Dani Irawan \\ Mechanical Engineering Department \\ Polytechnic of Kediri \\ Kediri, Indonesia \\ Email: the_boymaster2@yahoo.com line
}

\begin{abstract}
This study aims to determine: (1) the appropriateness of graduate learning achievement toward career fields that are in great demand of Diploma III students; (2) the appropriateness of graduate learning achievement toward career field which is less desirable by Diploma III students of mechanical study program Engineering Polytechnic Kediri. This research used survey method. The research population was all of Diploma III students of Engineering Program, Polytechnic Kediri which had implemented industry work practice or apprenticeship in 2014/ 2015 which amounted to 210 students. The sample size was determined by using guidelines from Krecjic and Morgan for 5\% error rate of 136 students. Sampling used stratified proportional random sampling method with the proportion of each stratum in $50 \%$. The data were collected by using a questionnaire which contained "A Self-Inventory for Career Planning", quoted from Werther and Davis (1996). Inventory was commonly used to determine the interest of employees in choosing a career. Respondents' answers were given in the form of numerical rating scale by assigning a score of 1 for the "yes" answer to the preferred job and the 0 value in the answer "no" for the unpopular job. Each student was given the opportunity to choose a maximum of 6 types of work preferred. The remaining types of work are not selected, it automatically got ' 0 ' score. Data analysis was done by using descriptive analysis in the form of a percentage.
\end{abstract}

Keywords-career, study program mechanical engineering, polytectic of kediri

\section{INTRODUCTION}

The ideal conditions to be achieved by Diploma III Kediri can be seen in the educational goals Wich was Wich was listed in the vision and mission which for the purposes of study program study program it is to Produce middle experts skill in the field of maintenance and repair of machinery, discipline, communication skills, have is entrepreneurial spirit, character, and have strong professional ethics (Document Curriculum Mechanical Engineering, 2016).

While Henry and Thomson in Berg (2002) describe polytechnic education as identical to learning "how to work", labor-oriented education seeks how to improve the technical competence and position of a person in the environment through the mastery of technology and vocational education closely related to the needs. Thus the Polytechnic is an educational institution that has the potential to prepare human resources that can be absorbed by the world of work, because the material theory and practical practices have been given since the first study, in the hope that Polytechnic graduates have competence in accordance with the needs of the work world.

As part of the national education system, the Polytechnic is a high level of education that prioritizes the development of students to be able to work in certain fields, to see job opportunities, adaptability to have in the work environment, and to develop themselves in the future. To realize the goals of national education, the curriculum Polytechnic is prepared by taking into account the KKNI level, it is conformity with the type of work and social environment. the needs of national development, the development of science and technology as well as the arts.

Yuen in sectors works closely to develop education for the workforce. He said that the number of vocational school graduates every year as many as 252,000 people, those weve far above the general education graduate who were only 60,000 people [6]. Added that South Korea and Malaysia were targeted by the end of the century by $50 \%$ of new students enrolled in senior high school who entered Polytechnic education [6] . Based on the above opinion,

Added that what distinguishes NICs from other developing countries is the quality of their workforce [5]. It was stated that in the newly industrialized countries (NICs), diligence, loyalty. hard work of the workforce, and a high appreciation for education are more abundant than other developing countries.

Problems that occur in mechanical engineering study program used KKNI curriculum version and SN DIKTI which set and attempt to do transformation or reconstruction of the existing curriculum to meet the demands of legislation, in addition to the preparation of accreditation requirements as conducted by BAN PT, It appears that the insemination of a new policy is done seriously and intensively in education.

However, this is not the case on standardization of positions or competency requirements commonly attributed to job vacancies, as one example published by the Metal and Machinery Certification Qualification Framework dividing the qualification level to six levels (I to VI). This happens for various types of employment, whether private sector or stateowned enterprises. It happens because there is no coordination between the relevant sections (education, employment, 
Job opportunities which are available for engineering graduates are diverse and various types of positions are offered. If a company can ensure that every graduate of a course will be admitted directly to the company, the study program will have no problem preparing a curriculu m based on the competencies desired by the company. Unfortunately, the condition is rare or even almost never found, so the existing study program will strive to map the possibility of the profile of graduates according to the diversity of existing positions, then try is hard also to determine the competence (Achievement Learning) which exists, then work hard also to translate it into existing courses (hard work efforts are layered) [4].

Therefore, the ideal career type to choose is a career that matches the learning achievement choices which set by the study program considering to Diploma III engineering students are prepared to become professionals in the field of the machine, Hence the need for various information related to the orientation of their real career choice. By having knowledge of this information it will help lecturers and students themselves in the future career pursue. Today the, information about the orientation of career choice of students, especially students of mechanical engineering diploma III is still lacking. In this connection, this research is important to get information as much as possible about student career choices.

Based on the above descriptions, in this study will discuss two issues, namely: (1) career choice in any field of work that many interested students of mechanical engineering diploma III Polytechnic Kediri ?; and (2) career choice in any job field that is less desirable by mechanical engineering diploma III Polytechnic Kediri?

\section{LITERATURE REVIEW}

Donald E. Super (1957) set out a vision of a wide-ranging career development, as the development of the post was seen as a process that included many factors. These factors are partly to the individual himself and to some extant in his or her environment which all interact with each other and together form the process of one's career development. Choice of position is a combination of various factors in the individual itself such as the needs of personality traits, intellectual abilities, and many factors outside the individual, such as the level of socio-economic life of the family, the variation of the demands of the cultural environment, and the opportunities / loosening that arise. The emphasis of these things lies in the factors in the individual himself.

A fundamental element in the view of Donald E. Super is the self-concept or self-image of the work to be done and the vocational self-concept. The concept of vocational self is part of the whole picture of oneself. The research data provide a strong indication that vocational self-concept develops during physical growth and cognitive development; this development takes place through the observation of persons holding certain positions, through identification with working adults, through living experience, and through the influence received from the environment. Awareness of the similarities and differences between self and all others, finally formed a vocational selfimage.
This self-image cultivates an internal drive that directs a person to an area of office that makes it possible to achieve success and to be satisfied (vocational satisfication). This causes a person to manifest a self-image in a field of the office most likely to express oneself. The concept of development also led to Super ideas about career patterns. From the work of Miller and Form (1951) and Davidson and Anderson (1937), Super expanded the concept of career patterns. People's career behaviors follow regular patterns that are predictable and predictable. These patterns are the result of the accumulation of various aspects of psychological, physical, situational, and social factors [3].

The concept of a career pattern shows that the life cycle imposes a different vocational task on people at different times of life. Attention to career choice as a decision that occurs in adolescence reflects only a vital segment of vocational behavior in an individual's life. To fully understand one's vocational life, the whole cycle must be observed. Super also notes the different roles of the environment and heredity in maturation and attention to aspects of the environment that can be manipulated to facilitate vocational maturity.

Compares approaches to career counseling from different theoretical perspectives, explain ing the steps involved in career development counseling [1]. The diagnostic stage is the ass ess ment phase that tries to deal with three areas of behavior: problems, people, and prognosis. Testing of different types and supplies of various types will be very reliable for generating data for diagnostic stages.

One characteristic of the Super theory is the application of concern for counseling on work and personal issues. Super reasoning that although self-concept tends to be a function of genetic influence on physical factors, such as glandular structures, and psychological factors, such as talent, it operates in combination with environmental variables, such as social and economic conditions. Thus, a certain part of the selfconcept is open to external intervention. Such interventions are perhaps the most effective in shaping self-concept during early adolescence, as the concept grows more stable during adolescence and adulthood. Counselors, therefore, have access to children during the greatest developmental years of selfconcept.

\section{METHOD}

This research includes survey research which in conducted for two months starting from July to August in 2017. The research population was of all D-3 students of mechanical engineering polytecknic of kediri to carry out the industry work practice that was the generation of 2014/ 2015 which amounts to 210 people. The sample size was determined by using guidelines from Krecjic and Morgan for a 5\% error rate of 136 people. Sampling used stratified proportional random sampling method with the proportion of each stratum of $50 \%$. It was taken at random. The research data was collected by using "A SelfInventory for Career Planning" [8]. Inventory was commonly used to determine the interest of employees in choosing a career. Respondents' answers were given in the form of numerical rating scale by assigning 1 score of to the "yes" answer to the preferred job and the 0 value in the answer 
"no" to the unpopular job. Each student was given the opportunity to choose a maximu m of 5 types of work preferred. The remaining types of unselected jobs automatically get 0 score 0 . The percentage determination is done by dividing the number of respondents who answered "yes" in the career field of interest with the total number of respeonden then the division was multiplied by $100 \%$. These criteria could be known as career profile orientation career Care and mechanical engineering Polytechnic of from a description of career field preferred and less preferred.

\section{RESULT AND DISCUSSION}

After analyzing the data on 12 types of work offered were students were selected, the findings of career orientation orientation of D-3 mechanical engineering Polytechnic of Kediri were obtained. Percentage calculation results for each career field could be listened to in Table 1 .

\section{TABLE I. CAREER FIELDS}

\begin{tabular}{|l|c|l|c|c|c|}
\hline \multirow{2}{*}{ No } & \multirow{2}{*}{ Career fields } & \multicolumn{2}{|l|}{ Yes } & \multicolumn{2}{l|}{ No } \\
\cline { 3 - 6 } & & Total & Total & \% \\
\hline 1. & $\begin{array}{c}\text { Mechanic } \\
\text { Engineer }\end{array}$ & 90 & 68,9 & 65 & 31,1 \\
\hline 2. & $\begin{array}{c}\text { Production } \\
\text { Engineering }\end{array}$ & 17 & 9,4 & 165 & 91,6 \\
\hline 3. & Engineering Staff & 18 & 10 & 126 & 90 \\
\hline 4. & Sales Engineer & 20 & 11,1 & 150 & 89,9 \\
\hline 5. & Engineer & 72 & 40 & 78 & 60 \\
\hline 6. & Mechanical & 127 & 70,5 & 63 & 39,5 \\
\hline 7. & $\begin{array}{c}\text { Project } \\
\text { Engineering }\end{array}$ & 114 & 63,3 & 66 & 36,7 \\
\hline 8. & Rigger & 19 & 73,3 & 38 & 26,7 \\
\hline 9. & CAD Technician & 15 & 8,3 & 155 & 91,7 \\
\hline 10. & $\begin{array}{c}\text { Maintenance } \\
\text { Manager }\end{array}$ & 132 & 10,5 & 141 & 89,5 \\
\hline 11. & $\begin{array}{c}\text { Mechanical } \\
\text { Supervisor }\end{array}$ & 126 & 70 & 54 & 30 \\
\hline 12. & $\begin{array}{c}\text { Operator } \\
\text { Engineering }\end{array}$ & 16 & 8,9 & 154 & 91,1 \\
\hline
\end{tabular}

The data in Table 1 showed that the five groups of career areas that become the priority of the students choice were: The less favored career areas by the D-3 of mechanical engineering students of Polytechnic kediri were: Mechanic Engineer, Mechanical Project Engineering maintenance manager. Priority of D-3's career choice of mechanical engineering study program could be ranked based on the rank of the most chosen career type to the least chosen career. The ranking of career options could be seen in Table 2.
TABLE II. RANKING OF CAREER OPTIONS STUDENT ORIENTATION MECHANICAL ENGINEERING

\begin{tabular}{|c|l|c|c|c|c|}
\hline \multirow{2}{*}{ No } & \multirow{2}{*}{ Career fields } & \multicolumn{2}{|c|}{ Yes } & \multicolumn{2}{c|}{ No } \\
\cline { 3 - 6 } & & Total & $\%$ & Total & $\%$ \\
\hline 1. & $\begin{array}{l}\text { Maintenance } \\
\text { Manager }\end{array}$ & 132 & 73,3 & 38 & 26,7 \\
\hline 2. & Mechanical & 127 & 70,5 & 63 & 39,5 \\
\hline 3. & $\begin{array}{l}\text { Mechanical } \\
\text { Supervisor }\end{array}$ & 126 & 70 & & \\
\hline 4. & $\begin{array}{l}\text { Project } \\
\text { Engineering }\end{array}$ & 114 & 63,3 & 54 & 30 \\
\hline 5. & \begin{tabular}{l} 
Mechanic Engineer \\
\cline { 3 - 6 }
\end{tabular} & 90 & 68,9 & 66 & 36,7 \\
\hline
\end{tabular}

Table 2 showed the attitude of students less like to the types of work done outside the building. However, admin is trative work that was commonly done in buildings such as written work and clerical work was also not desirable. Students also did not like the type of social work such as oral work and interpersonal work. Students were less fond of jobs that require literacy, jobs dealing with the maintenance of documents, and a lot of work dealing with people could be understood because in the learning process, especially practical learning, the students were more dealing with things that were concrete, rational and using the logical thinking and mathematical thinking work independently.

Based on the above findings, the study program, especially the department of care and improvement of the Machine, needed to develop programs that were learning and coaching that can add students' insight into the various fields of a career in the community. The career coaching was integrated into each subject, especially the courses that equip students' ability to entrepreneurship. Industrial practice programs could be used by students to get closer to their career choices with the real work context. In order for student career orientation to be more stable and students could develop the potential based on their career choice then cooperation with entrepreneurship practitioners and DUDI need to be improved so that student learning rides became more concrete.

\section{CONCLUSION}

Based on the findings on the research results, then it can be concluded:

1. Career field that much in demand of Diploma III mechanical engineering students is as follows:

a. Managerial work (managerial work).

b. Work that requires creativity (creative work).

c. Mechanical work (mechanical work).

d. Works which is related to physical, many using hands (physicalwork).

e. Analytic work.

2. Career fields that are less desirable Diploma III mechanical Engineering student are as follows

a. Work in the field of observation (visual work).

b. Work calculate (quantitative work). 
c. A lot of work outside the building (outdoor work).

d. Work in reading and writing (written work)

e. Jobs that deal with many others (interpersonal work).

f. The work takes care of document maintenance (clerical work).

\section{REFERENCES}

[1] Crites, J. O, Career Counseling: Models, Methods, and Materials. New York: McGraw Hill, 1981.

[2] Irawan, Dani, Document Curriculum Mechanical Engineering, Kediri, Polytecnic of Kediri, 2016.

[3] Osipow, S.H, Theories of Career Development (3rd ed). New Jersey: Prentice-Hall International Inc, 1983.

[4] Peter Z. Schochet. Promoting core skills through cooperative learning. Dune, A. (Ed.): The Learning Society.pp: 140-148. London: Kogan Page Limited, 2011.

[5] Rhunsen, D, collaborative model for scholl reform thought a rural school/ university partnership. Education journal. 126(2): 364-368, 2008.

[6] Rojewski, J.W, A Conceptual Framework for Technical and Voctional Education and T raining: Germany: Springer Science Media, 2009.

[7] Super, D. E, The psychology of career. New York: Harper \& Brothers, 1957. 